\title{
Language Exercises in Geography and History Books, to Help the Acquiring the Scientific Knowledge
}

\author{
Mariola Haxhiu \\ Phd candidate at Albanological Studies Center \\ mariola_haxhiu@hotmail.com
}

\begin{abstract}
An important tool in the acquisition of scientific knowledge in the different school subjects is language and its practical exercise. Using them in the scientific subjects requires teachers to pay them proper importance,to know to choose the exercises by the level of students, but also to have language skills that help students to acquire soon and absorb better the Non-linguistic subjects.

The hypothesis that we takeis that the combination of linguistic and scientific exercises affects in training the students, in understanding and expressing in Albanian as well as in the learning of the knowledge in the school subjects.But in what way it is built the practical side of scholarly textsand how they help in the acquisition of the knowledge? In response to this question, we analyzed some of the exercises in the textbooks of history and geography.

At the beginning of the work is given a theoretical statement about the importance of the Albanian language at school.Then is analyzed the new curriculum and the inclusion of language in it.The practical side of this work consisted of analyzing the linguistic exercises used at the various books of history and geography of the nineyear education
\end{abstract}

Keywords :scientific communication, Albanian language, linguistic exercises, school knowledge.

\section{INTRODUCTION}

"Education is mainly a linguistic process. "This statement is taken from the book introduction (2004) Mary J. Schleppegrell "Language education"which means language teaching and learning in the classroom. The educational process is complex and multidimensional.However, Schleppegrell justifies her position as follows:

- To expand knowledge gained at school, students should learn to use language in different ways.A brief survey of each class is sufficient to show the role of language not only at carrying out different activities, but also at presentating the content. Teaching School subjects is done by means of language, as well as learning and their assessment.Additionally,language skills are part of the educational content;students learn to write words, sentences, to define, to become interested in language as a whole.In other words, the content of education is language. (Schleppegrell 2004.1-2)

\section{Language and its Impact on other Subjects}

Language and all means of communication play an important role in the teaching of other subjects,other than the language as a separate subject.Language skills that students benefit from everyday life and the social environment in which they live is not enough to assimilate the know ledge that appear in various school subjects.Every student has the right to to be provided with basic language skills which will help further develop his knowledge. While the language as a subject in itself has obviously other objectives.

Language education should not be confined within the the subject of language,Linguistic formation is important in learning other school subjects, which require different communication skills:

- Reading and understanding of the informational texts, the structure of which depends on the subjects where they are developed,

${ }^{1}$ MARY J. SCHLEPPEGRELL, The language of schooling: A functional linguistics perspective 2004, pg 1-2 
- Listening to the teachers explanation on various complex topics,

- Answer questions submitted in writing and orally,

- Take part in discussions and debates on various topics

Acquisition of the knowledge in different subjects can not be done without the linguistic intercession.Learning is possible only by using the right means of the language. Consequently, the linguistic ability is an integral part of various school subjects.Language skills are developed in parallel with the knowledge obtained in different subjects by the student, being closely related to each other.This should be respected in all cases and for all the curriculum,because linguistic dimension is closely related to thinking.

Often school is responsible for the students failure,this because language and communication requirements inherent in different subjects and the students are not informed about this. Not only so,but these skills are self-learned,Without paying special attention in class.Most of the teachers are not prepared to explain to students the linguistic challenges of schooling.

From what we mentioned above, when we talk about language as a tool in teaching and learningWe refer to all the linguistic forms that appear in their classroom and students communicate through,discuss, exchange opinions pro and against, argue.Thanks to which students reach their conclusions and inferences. They serve to promote critical thinking among students.

The task of communicating in different subjects is not easy.The student comes to school with a linguistic knowledge acquired from everyday life or from grades predecessor.It is the duty of every teacher to expand the students' linguistic knowledgeputting it in terms of any school subject,to stimulate logical learning and argumentation. The recognition of the important role of language and communication in other subjects presents major challenges for all interested parties in education. This means that the teachers of any subject should have greater sensitivity to the language used in their coursesand to cooperate more closely in the management and integration of different communication levels in their fieldand the integration of different subjects for this purpose. The curriculum developers on the other hand should pay greater attention to language as a tool and a key factor in teaching and learning.

In conclusion, the use of language in other school subjects is summarized in four points kye:

- Talking about teaching subject

- Learning a subject and interaction

- Interpretations of different issues addressed in various subjects

- Thinking and reflecting on what you learn in dealing with these cases

\section{The language in the curriculum scince 2014}

In the years 2014-2015 we have a new approach to the curriculum, basing it on competencies. The reformed curriculum implements curricular approach based on powerswhich enables the construction of competencies of students;integrates courses in a coherent whole;clearly aimed at learning the curriculum that transcends the boundaries between subjects; It creates equal opportunity for success for all studentsand provides solutions that respect the individual learning styles and learning from previous experiences, as conditions to improve achievement levels.

The selected curricular model is inspired by an effective theory of knowledge and logic of the new curriculum. At the foundation of this model is the idea that the acquisition of knowledge in the learning process aimed at finding the answers to pose real situations,placing links between subject knowledge and life contexts arguing that knowledge it is associated with situations.

The current curriculum, which puts an emphasis on subject contents, purpose of learning, has suggested that students to be taught the subject, to understand them better and to implement them in standard situations.

Albanian language subject helps to develop the key competences in history and geography,such as powers of communication and expression and the power of thought. 


\section{a. Thinking Competences}

The student develops critical and creative thinking in the evaluation of dataand their use, test explanations and analyzes the arguments.He develops the skills for making decisions and strategies that help to think analytically and logically.The program enables the learner to understand the value and process direction of the questions,to be creative and develop the imagination in making field observations. The student is encouraged to think critically and creatively about ways of rational use of natural resources.

\section{b. The Competence of Communication and Expression}

The geography program creates opportunities for the development of communication skills. The student uses printed material, visual and digital, to explore phenomena, geographical processes, countries and regions. Through the skill of expression he discusses the role plays, debates or does presentations; progressively develops and uses geographical dictionary for communicating information and ideas to different audiences. An important point of connection of new programs remains the subject of the geography or history in the field and with other areas of learning.

Geography is closely connected with other areas of learning. Like all the other subjects, geography creates opportunities enforcement powers that develops fields "Languages and Communication". The student develops his skills and communication skills, written and oral, to seek and communicate its findings. He uses the literary language to express his position clearly and coherently. But at the same time even geography contributes in the enhancement and processing of the students vocabulary, by inciting him to submit clearly and precisely his ideas, either orally or in writing. The practical works, which are very important for the development of competences of this subject, give to the students the opportunity to develop communication competence and enrich the language glossary.

On the other hand the subject of history and the Albanian language should be integrated mutually to each other. Only in this way can be implemented as the key learning competencies and goals of the school and society in the field of education. So, history can use the knowledge, concepts and skills in the Albanian language to concretize and to argue better knowledge, skills, attitudes and its values.

\section{The connection between history and language:}

- Interpret historical texts by means of various forms of communication.

- Express opinions, reasons, discusses, argues and does argumentative debate with historical themes.

- Select proper historical information in text.

- Uses spelling rules for writing a historical material.

- Distinguishes various literary genres: diaries, memoirs and historical novel.

- Uses literary and artistic works, as a source of historical information.

All that Mentioned above are the Result of 4 De velops Powers of Language and Communication Areas:

\section{Listening}

Students demonstrate appropriate behavior and attitudes during the listening process as: attention, eye contact, consent, encouragement and interest.They listen and understand a variety of texts and express opinions and their assessment of these texts.

\section{Speaking}

Students spell correctly and with proper intonation and accent of words and sentences,in order to be understandable and interesting to others;use during speech also non-verbal elements of communication;discuss and interact with others during group work.

\section{Reading}

Students read literary and non-literary texts belonging to different periods,classical and contemporary texts, in Albanian and other languages and demonstrate understanding, interpretation, analysis, evaluation and assessment of these texts. 


\section{Writing}

Students write for various purposes and listeners. They follow during the writing process steps as: planning, organizing ideas, review and editing. Students also observe the structure, text features, and linguistic rules.

\section{The right us age of the language}

Students to speak and write properly, then they must possess knowledge, demonstrate skills, values and attitudes about the linguistic system of Albanian and foreign languages. Like this students recognize different parts of speech, grammatical categories and use them in the proper form of the communication; recognize different types of sentences and functions of words in sentences and apply this knowledge in everyday communication; use standard language, recognize dialects other parts of the vocabulary and respect linguistic diversity; have knowledge about ways of forming words in the Albanian language, distinguish the meanings of words and use them to enrich their vocabulary.

\section{The Methodology and Analys is of the Study}

The method used is the descriptive analysis of linguistic exercises in various texts of history and geography in secondary education

In analyzing the linguistic activities in support of the acquisition of knowledge in the subjects of history and geography are taken to study a large part of different books publishers and different editions. The purpose of this study is to analyze the importance of linguistic exercises and the ir impact on the acquisition of scientific knowledge.

\section{Results and Interpre tation}

Example 1: (Geography 6, pg.27, Shblsh, 2003)

Lesson title: The vital envrioinment of the average areas

\section{Questions and assignments}

1. Show on map the expansion the vital envrioinment in the average areas?

2. Natural landscapes what features have broadleaved forest? and where they lie?

3. Describe the appearance of coniferous forests also indicate their location on the world map

In the recent years students used to learn by heart or memorize.The answers to these questions are all made in the text and it will be enough if the student just read it. Besides training in reading and learning mechanical reproduction, these questions do not develop any other skills to the students.

In 2006 we see a significant change in the organization of the questions at the end of the lesson.In the book of history 7, 2000. Day of the publisher of in 2006, this difference begins with naming the new entitled "Thinking through history."Inside this section are located exercises of various types according to the level of the studentsStarting with the exercise "Take notes," student practiced with work tables, to pass later in the construction of the tables by them.

A special attention in this book is devoted to the work with the dictionary. Almost all of this book lessons with vocabulary exercises, entitled:"Have fun (Use the new terms and names.)".Students are given the opportunity to discuss and express their opinions through the rubric "Discussion".This method enables students to participate in the learning process and work together with each other. The method of Discussion has as the main aim the collaboration.Cooperation is the key criterion for success. To promote critical thinking, the teacher must constantly attract students into the appropriate experience,which support their intellectual, social, and personal development.This view of the teachers meet best section titled "Protect"which allows students to defend their ideas by arguing them.

Example: ( History 7, fq.34, Dita 2000, 2006)

Titulli i mësimit: Anglia- naval power and constitutional monarchy.

Protect- "Declaration of Rights" restricts the authority of the king.

In the this type of exercise, the student by means of language and its correct use will show what has he been able to adopt during this class. 
The Rubric "Opinion" is another activity that promotes the logic learning.Learning is fruitful if speech, talk, socialize and associated with actions,exercises and working or acting. Acting means that the student is set free to spread across his knowledge of culturally and linguistically to give his opinion about the given issue.In the course of these exercises we can mention other exercises like "Judge", "Analyze", "argue".

Under the heading "Check the knowledge" appears the exercises history book 8 of the publisher "Albas" published in 2007.In the this section we find a variety of activities.A special place is given to the vocabulary.In the this wide range of exercises, the teacher is free to choose the activity that he seems the most effective to check the knowledge gained from his students. Below are some examples of exercises taken from this book: On the Exercises book of History 9, from the Ideart publisher 2009, is presented under the title "individual works and assignments". Under this heading are listed a number of different types of exercises such as:

- Justify statements

- Check knowledge

- Explain

- The practical Skills

- Try the memory

- Discuss

This variety of exercises besides serves to measure the meaning of the text and knowledge gained,It also serves to encourage the students to debate and work in groups.this kind of texts allow teachers to focus also on language issues.

The history book 6 publisher Pegi 2012 offers not only historical knowledge, but also the means of a set of exercises entitled "Try the knowledge and reasoning"This book aims to develop students' ability to analyze and interpret ot historical information critically,by means of dialogue and the search for truth through open debate.

The history book 7, publisher Ideart 2012 pays the space required after learning exercises, which are summarized under the heading "Questionnaires and The practical activities".The activities of this section are of different types: exercises with the explanation, the grounding, description, scheme or table exercises, etc.These exercises make the students able to read an image or a table. In the this book, we will face also essay.

Example 3: (History 7, fq. 49, Ideart, 2012)

\section{Lesson title: Development of Revolution}

\section{Question: Write an essay indicating the Topic "Revolutionary France"}

Even in the history book 7, publisher Morava 2012 , the publisher Morava follows the same format in the formulation of a lesson and exercises that come after it. rubric by means of "The dikutojmë and rule together", students can be involved in teaching in many different forms They can see on a given factcan compare the two phenomena, can justify or argue a given expression, can give their opinion and discuss with classmates.In the this book are often treated type of exercises cause and effect.

The history book 8, publisher Albas 2013 It presents another view of the exercises. The exercises in this book are divided into two categories:The first category which summarizes the exercises by the type of: Underline, lists, names, show argues, make a description. All verbs exercises are highlighted in bold.These exercises belong to students basic and intermediate level.There are exercises that demonstrate understanding of the text directly by students.

The second category encompasses exercises a higher level.There are exercises that require follow up on what is required.The student must put in work all logic and uses his knowledge of the language that the transmission of ideas come out correctly.Among these exercises we may include: 
Example 4: (History 9, pg. 8, Albas, 2013)

Lesson title: The early inhabitants of our country.

Question 2: Heroidi of Strabo what did thy say for the antiquity?

Pelasgians were accustomed to sacrifice for the gods everything.The gods, having put all things in order, bearing the laws of the universe. (Heroidi, ctr. V BC.)

a. The oracle of Dodona was built by the Pelasgians. For the latter rumored to have been the oldest of all those who ruled in Elad (Straboni, I ctr).

\section{Explain the Lessons Extracted from these two Documents and the in Bold Parts}

The realization of this exercise, apart from a good learning acquisition also requires very good language communication skills and.The student is asked not only for the acquisition of learning, but for all his knowledge and his communication skills,expressive in the center of which lies the critical thinking. In the this way the student expresses himself.

2015 books are books that have undergone to a long and rigorous competition. They were selected on the basis of standard texts through an open competition, equal and transparent.

The history book 6 publisher Morava,the student, along with the development of historical competencies, develops the key competencies also about solving the problem,creativity, innovation, information processing, presentation tasks, teamwork and effective communication

The exercises in this book are summarized under the heading "To discuss and work together."All exercises are intended to control the addition of knowledge, developing students' communication ability and speech, the ability of thinking and learning. Through argumentation and reasoning exercises, students use historical texts language functions:extensive use of nouns, adverbs and adjectives to describe places, people and events. This section will also encountered supplement exercises or work tables with different schemes, which help students to interpret and then build graphic.A characteristic of this book is the section "Enjoy"which emphasizes the importance of vocabulary.In the form of a game that aims to make students part of the habits of the relevant historical dictionary.

The history book 6 publisher "Albas"It differs not only for a variety of exercises from the title set, but in space it devotes to these exercises. "Trace-think-reason-draw conclusions" is the title set for the exercises in this book. Suffice it to read the title to understand how much exercise was made available to students to realize and express their learning. On the other hand, these exercises also made available for the teachers, to create the appropriate atmosphere and conducive for teaching, where in the center of the life we have always the studentand his skills.

and his skills.Illustrations of the book are rich and relevant explanations. Often they are made in the focus of the exercises.

Example 5: (History 6, page. 49, Albas, 2015)

\section{Lesson title: Changes in European medieval civilizations}

Question: Interpret the caricature "feudalism".

On this book are offered various forms of development and organization of the class, where dominates the one with the student in the center as an individual, but also as a whole class. These methods or techniques in itself contain elements psychological, social and didactic that better use psychological and social energies of each student.

The geography book 6 publisher "Pegi", except for the realization of program objectives, it aims to develop the skills to be critical and creative users of geographic research methods. Attention is paid to training of the students as active and responsible citizens. The process of learning in this book takes place by means of continuous confrontation of critical and creative thinking.

\section{CONCLuSiONS}

We more and more in the texts are find grounding exercises, with judgment, with analysis, exercises that require the construction of causal relations.From books of 1998 we started our analysis, to those of 2004, the exercises are summarized in the section "Questions and assignments".These questions consisted only in mechanical reproduction of teaching provided. 
After 2004, the books of history and geography are enriched with a variety of exercises that promote learning language and logical,make students think critically about various historical facts or geographical phenomenon.the books Rankings with a variety of exercises in 2015,where one of the required standards in the publication of the book referred to linguistic aspects, according to which the language of the textbook should be in accordance with the norms of standard language.

Mostly, the linguistic exercises encountered in different books of history and geography of the year 2012-2015.They aim to develop students' ability to analyze and interpret historical informationCritically, by means of dialogue and the search for truth through open debate.

The linguistic exercises remain important because, except for the realization of program objectives, have also develop skills to be critical and creative users of geographic research methods. Thanks to them, the process of learning takes place by means of continuous confrontation of critical and creative thinking.

What remains to be said that recently Is the significance of the inter-subject action as the key to forming successful individuals. The language represents an essential component of the teachinglearning situations.You can not speak to approach the teaching-learning context without focusing on linguistic framework. The language is a fundamental element of the educational process in its entirety.

\section{REFERENCES}

Gjeografia 6, fq.27, Shblsh, 2003

History 7, fq.34, Dita 2000, 2006

History 7, fq. 49, Ideart, 2012

History 6, page. 49, Albas, 2015

History 9, pg. 8, Albas, 2013

MARY J. SCHLEPPEGRELL, The language of schooling: A functional linguistics perspective 2004, pg 1-2.

Les Curriculums Nationaux des Langues pour le système éducatif pré-universitaire, (2000), Toena, p. 5.

La maîtrise de la langue au collège, Ministère de l'éducation nationale, de l'enseignement supérieur et de la recherche, Direction des Lycées et Collèges, CNDP-Savoir lire, 1997. Pg. 37

VOLLMER, H. (2006b) : Langues d'enseignement des disciplines scolaires, Strasbourg, Conseil de l'Europe, Division des Politiques linguistiques.

Cadre européen commun de référence pour les langues : apprendre, enseigner, évaluer (2001), Strasbourg, Conseil de l'Europe, Division des Politiques linguistiques. 